\title{
Effect of temperature on immatures of Stiretrus decastigmus (Hemiptera: Pentatomidae)
}

\author{
S. Poncio ${ }^{a}$, S. T. B. Dequech ${ }^{a, b}$, A. Bolzan ${ }^{b}$, C. Güths ${ }^{b}$, M. P. Walker ${ }^{b}$, \\ V. S. Sturza ${ }^{b}$ and D. E. Nava \\ aPrograma de Pós-graduação em Agrobiologia, Universidade Federal de Santa Maria - UFSM, \\ Av. Roraima, 1000, Cidade Universitária, Camobi, CEP 97105-900, Santa Maria, RS, Brazil \\ bDepartamento de Defesa Fitossanitária, Universidade Federal de Santa Maria - UFSM, \\ Av. Roraima, 1000, Cidade Universitária, Camobi, CEP 97105-900, Santa Maria, RS, Brazil \\ 'Laboratório de Entomologia, Embrapa Clima Temperado, Rodovia BR 392, Km 78, CP 403 , \\ CEP 96010-971, Pelotas, RS, Brazil \\ *e-mail: soniaponcio@yahoo.com.br
}

Received: October 20, 2014 - Accepted: April 23, 2015 - Distributed: May 31, 2016

\begin{abstract}
Stiretrus decastigmus (Herrich-Schaeffer) (Hemiptera: Pentatomidae) is an important predator of the insect pest Microtheca ochroloma Stal (Coleoptera: Chrysomelidae). The present study investigated the pre-imaginal development of $S$. decastigmus at different temperatures. The temperatures were: 20,25 , and $30{ }^{\circ} \mathrm{C}$, with a relative humidity of $70 \pm 10 \%$ and a photofase of $12 \mathrm{~h}$, and the nymphs were fed larvae of M. ochroloma. We evaluated the duration and viability of the egg and nymphal stages, the duration of each instar, and the predation potential. The incubation time decreased with increasing temperature, and the viability was highest at $25{ }^{\circ} \mathrm{C}$. The duration of the nymphal stage was inversely proportional to the temperature, ranging from 18 days at $30^{\circ} \mathrm{C}$ to 40.6 days at $20^{\circ} \mathrm{C}$. The highest $S$. decastigmus predation rates were found at $20^{\circ} \mathrm{C}(90.4$ larvae $)$ and $30^{\circ} \mathrm{C}(72.5$ larvae $) . S$. decastigmus showed the highest viability and lowest consumption of larvae of $M$. ochroloma at $25^{\circ} \mathrm{C}$.
\end{abstract}

Keywords: Asopinae, Chrysomelidae, biological control, predator.

\section{Efeito da temperatura sobre imaturos de Stiretrus decastigmus (Hemiptera: Pentatomidae)}

\section{Resumo}

Stiretrus decastigmus (Herrich-Schaeffer) (Hemiptera: Pentatomidae) é um importante predador do inseto-praga Microtheca ochroloma Stal (Coleoptera: Chrysomelidae). O objetivo deste trabalho foi estudar o desenvolvimento pré-imaginal de $S$. decastigmus em diferentes temperaturas. Foram utilizadas as temperaturas de 20,25 , e $30{ }^{\circ} \mathrm{C}$, umidade relativa do ar de $70 \pm 10 \%$ e fotofase de $12 \mathrm{~h}$, sendo as ninfas alimentadas com larvas de M. ochroloma. Foram avaliados a duração e viabilidade dos estágios de ovo e ninfa, a duração de cada instar e o potencial de predação. O período de incubação diminuiu com o aumento da temperatura e apresentou maior viabilidade a $25^{\circ} \mathrm{C}$. A duração do estágio ninfal foi inversamente proporcional a temperatura com 18 dias a $30^{\circ} \mathrm{C}$ e 40,6 dias a $20^{\circ} \mathrm{C}$. A maior taxa de predação de $S$. decastigmus foi encontrada a $20{ }^{\circ} \mathrm{C}$ (90,4 larvas) e $30{ }^{\circ} \mathrm{C}$ ( 72,5 larvas). S. decastigmus teve maior viabilidade e menor consumo de larvas de $M$. ochroloma a $25^{\circ} \mathrm{C}$.

Palavras-chave: Asopinae, Chrysomelidae, controle biológico, predador.

\section{Introduction}

Production of vegetables such as species of Brassicaceae is an excellent option for family farms, especially in organic systems (Pinto et al., 2001). However, the plants are attacked by the insect pest Microtheca ochroloma Stal (Coleoptera: Chrysomelidae), which defoliates the plants during both its larval and adult stages (Fasulo, 2005). The impacts of this pest on crops is well documented in South America, where it is indigenous, and in North America (Ameen

and Story, 1997). The extent of the damage may impel farmers, especially organic producers, to avoid cultivating Brassicaceae (Dequech et al., 2008).

As an alternative to chemical pesticides, biological control using natural enemies has been increasing in importance in integrated pest management programs (IPM), especially to promote sustainability of agriculture (Parra et al., 2002). 
The natural enemy of Microtheca species, Stiretrus decastigmus (Herrich-Schaeffer) (Hemiptera: Pentatomidae), has been recorded in the state of Rio Grande do Sul, southern Brazil, preying on larvae and adults of $M$. ochroloma (Poncio et al., 2010) and M. semilaevis Stal (Sturza et al., 2012). However, little is known of the biology of this predator, a promising agent for biological control programs targeting this pest. In order to implement biological control, it is necessary to determine the effects of abiotic factors on the development of the predator. The present study examined the effect of different temperatures on the pre-imaginal development of $S$. decastigmus, with a view toward rearing the species in the laboratory for the purpose of biological control of M. ochroloma.

\section{Material and Methods}

\subsection{Establishment and rearing of Microtheca ochroloma}

Adults of M. ochroloma were collected from plots of Chinese cabbage (Brassica chinensis L.) (Brassicaceae) at the Universidade Federal de Santa Maria (UFSM) in the state of Rio Grande do Sul, municipality of Santa Maria, southern Brazil (29 43' 28' S, 53 43' 19' W, altitude: $95 \mathrm{~m}$ ). The adults were kept in rearing cages (transparent plastic boxes measuring $30 \times 30 \times 20 \mathrm{~cm}$ ), with mesh sides and cover) and fed with Chinese cabbage leaves pre-washed in running water. Water was provided to the insects by capillary action through cotton dental rolls that were placed in plastic containers containing $100 \mathrm{~mL}$ of water and changed every two days. The egg masses were removed from the leaves and placed in Petri dishes $($ diameter $=8.5 \mathrm{~cm})$ with their bottoms covered with filter paper. The larvae from these egg masses were kept in cages similar to those used for adults, but smaller $(17.7 \times 26.2 \times 14.7 \mathrm{~cm})$, and were also fed with leaves of Chinese cabbage, which were replaced daily. After the adults emerged, they were transferred to the larger cages for mating. Part of the insects, in various stages of development, were used to maintain the rearing stock, and part were used for the experiments. The creations were maintained at $23{ }^{\circ} \mathrm{C}$, with a relative humidity of $70 \pm 10 \%$ and a photofase of $12 \mathrm{~h}$.

\subsection{Establishment and rearing of Stiretrus decastigmus}

Nymphs and adults of $S$. decastigmus were collected from plots of Chinese cabbage (Brassica chinensis L.) (Brassicaceae) at the UFSM. The insects were taken to the laboratory and kept in cages $(17.7 \times 26.2 \times 14.7 \mathrm{~cm})$. Their eggs were removed daily and kept in Petri dishes (diameter $=8.5 \mathrm{~cm}$ ) with the bottoms covered with filter paper moistened with distilled water, until they reached the second instar. The nymphs were then transferred to breeding cages $(17.7 \times 26.2 \times 14.7 \mathrm{~cm})$ because they begin to predate in this stage. Larvae and/or adults of $M$. ochroloma were used as prey for $S$. decastigmus nymphs and adults, in laboratory rearing. The creations were maintained at $23{ }^{\circ} \mathrm{C}$, with a relative humidity of $70 \pm 10 \%$ and a photofase of $12 \mathrm{~h}$.

\subsection{Effect of temperature on the immatures of Stiretrus decastigmus}

Biological parameters of $S$. decastigmus were evaluated at temperatures of 20,25 and $30{ }^{\circ} \mathrm{C}$. Forty eggs of this predator were used per temperature, in a Petri dish $(9.0 \mathrm{~cm}$ diameter $\times 1.5 \mathrm{~cm}$ height) lined with filter paper moistened with distilled water to reduce egg dehydration. At each temperature, 20 second-instar nymphs were placed in individual cages prepared from plastic pots $(350 \mathrm{~mL})$. The experiments began with second-instar nymphs, because the first-instar nymphs do not feed (Zanuncio et al., 1991; Silva et al., 1996; Wanderley and Ramalho, 1999). The upper opening was closed with voile fabric to allow aeration. An acrylic container $(2.5 \mathrm{~cm}$ diameter $\times 4.5 \mathrm{~cm}$ height) was placed inside the cage, containing moistened cotton dental rolls to supply water. The nymphs were fed with third- and fourth-instar M. ochroloma larvae, offered to the nymphs in similar proportions ad libitum, and the larvae were left inside the cage until the nymphs reached the final instar.

The duration and survival of the embryo and nymphal stages, the number and duration of instars, the total life-cycle duration, and the number of prey consumed were assessed. The duration and survival were determined daily, when nymph hatching was recorded. The number and durations of instars were determined based on the interval between ecdyses, determined by the presence of molts in the rearing container. The total duration of the nymphal stage was taken as the sum of the duration of each nymphal stage. The overall life cycle was the sum of the durations of the egg and nymphal stages.

\subsection{Data analysis}

The experiments used a fully randomized design with 20 replications. Data normality was checked with Shapiro-Wilk's test (k samples) before analysis of variance (ANOVA); means were compared using Tukey's test $(\alpha=0.05)$. The ASSISTAT 7.5 Beta (2008) software was used (Silva, 1996).

\section{Results}

The incubation period of $S$. decastigmus was inversely proportional to the temperature, i.e., 5.00 and 13.66 days at 30 and $20{ }^{\circ} \mathrm{C}$, respectively (d.f. $=2 ; \mathrm{F}=127.5851$; $\mathrm{P}<0.001)$. Eggs kept at $25^{\circ} \mathrm{C}$ had the highest survival, and more individuals reached the nymphal stage (95\%). At this temperature, the egg incubation period of 8.57 days was intermediate between those at the other temperatures.

The temperature also affected the duration of all nymphal instars (Table 1). Nymphs kept at $20^{\circ} \mathrm{C}$ had a longer instar duration than those at 25 and $30^{\circ} \mathrm{C}$. The duration of the final instar was longer at all temperatures. The duration of the nymphal stage varied from 18.00 days at $30{ }^{\circ} \mathrm{C}$ to 40.60 days at $20^{\circ} \mathrm{C}$ (d.f. $=2 ; \mathrm{F}=174.4424 ; \mathrm{P}<0.001$ ). Nymphal survival was highest $(85.00 \%)$ at $25^{\circ} \mathrm{C}$, lasting 
Table 1. Duration (days) of nymphal instars (mean $\pm \mathrm{SE}$ ) and survival of Stiretrus decastigmus (Hemiptera: Pentatomidae) fed on Microtheca ochroloma (Coleoptera: Chrysomelidae) larvae at 20, 25, and $30^{\circ} \mathrm{C}$.

\begin{tabular}{ccccccc}
\hline \multirow{2}{*}{$\begin{array}{c}\text { Temperature } \\
\left({ }^{\circ} \mathbf{C}\right)\end{array}$} & $\mathbf{1}^{\text {st }}$ & $\mathbf{2}^{\text {nd }}$ & $\mathbf{3}^{\text {rd }}$ & $\mathbf{4}^{\text {th }}$ & Total \\
\cline { 2 - 6 } & $4.91 \pm 0.22 \mathrm{aD}$ & $7.27 \pm 0.14 \mathrm{aB}$ & $6.40 \pm 0.16 \mathrm{aC}$ & $7.88 \pm 0.20 \mathrm{aB}$ & $13.80 \pm 0.37 \mathrm{aA}$ & $40.60 \pm 0.81 \mathrm{a}$ \\
20 & $2.55 \pm 0.12 \mathrm{bC}$ & $4.00 \pm 0.14 \mathrm{bB}$ & $3.11 \pm 0.08 \mathrm{bC}$ & $4.70 \pm 0.25 \mathrm{bB}$ & $8.35 \pm 0.33 \mathrm{bA}$ & $22.70 \pm 0.47 \mathrm{~b}$ \\
30 & $2.83 \pm 0.30 \mathrm{bB}$ & $2.60 \pm 0.24 \mathrm{cB}$ & $3.40 \pm 0.24 \mathrm{bB}$ & $3.00 \pm 0.28 \mathrm{cB}$ & $5.25 \pm 0.47 \mathrm{cA}$ & $18.00 \pm 1.41 \mathrm{c}$ \\
\hline
\end{tabular}

Means followed by the same lowercase letter per column and uppercase letter per row did not differ by Tukey's test $(\alpha=0.05)$.

Table 2. Larval consumption (mean $\pm \mathrm{SE}$ ) per instar and total consumption of Microtheca ochroloma (Coleoptera: Chrysomelidae) larvae by the Stiretrus decastigmus (Hemiptera: Pentatomidae) nymph stage fed at 20,25 , and $30{ }^{\circ} \mathrm{C}$

\begin{tabular}{|c|c|c|c|c|c|}
\hline \multirow{2}{*}{$\begin{array}{c}\text { Temperature } \\
\left({ }^{\circ} \mathrm{C}\right)\end{array}$} & \multicolumn{4}{|c|}{ Instar } & \multirow{2}{*}{$\begin{array}{c}\text { Nymph } \\
\text { consumption }\end{array}$} \\
\hline & $2^{\text {nd }}$ & $3^{\text {rd }}$ & $4^{\text {th }}$ & $5^{\text {th }}$ & \\
\hline 20 & $4.63 \pm 0.45 \mathrm{aC}$ & $8.80 \pm 0.71 \mathrm{bC}$ & $18.00 \pm 1.39 \mathrm{aB}$ & $58.20 \pm 4.11 \mathrm{aA}$ & $90.40 \pm 4.23 a$ \\
\hline 25 & $4.27 \pm 0.22 \mathrm{aD}$ & $10.58 \pm 0.40 \mathrm{bC}$ & $14.88 \pm 0.66 \mathrm{aB}$ & $23.11 \pm 0.97 \mathrm{cA}$ & $52.88 \pm 1.11 \mathrm{c}$ \\
\hline 30 & $4.00 \pm 0.89 \mathrm{aC}$ & $14.40 \pm 2.14 \mathrm{aBC}$ & $19.40 \pm 3.78 \mathrm{aAB}$ & $33.25 \pm 6.71 \mathrm{bA}$ & $72.50 \pm 9.46 b$ \\
\hline
\end{tabular}

Means followed by the same lowercase letter per column and uppercase letter per row did not differ by Tukey's test $(\alpha=0.05)$.

22.70 days, whereas at 20 and $30{ }^{\circ} \mathrm{C}$ the duration was 18.0 and 40.6 days, with survival rates of 25 and $20 \%$ respectively. The total life cycle of $S$. decastigmus lasted $23.0,32.2$, and 54.0 days at 30,25 , and $20^{\circ} \mathrm{C}$, respectively (d.f. $=2 ; \mathrm{F}=215.9122 ; \mathrm{P}<0.001$ ). The predation rate of S. decastigmus was highest at $20^{\circ} \mathrm{C}$, when each predator nymph preyed on a mean of $90.40 \mathrm{M}$. ochroloma larvae (d.f. $=3 ; \mathrm{F}=38.0827 ; \mathrm{P}<0.001$ ) (Table 2). At all temperatures, consumption was proportional to the increase in size of the nymphs, i.e., the older nymphs consumed more prey (Table 2).

\section{Discussion}

The embryonic period of $S$. decastigmus was relatively long for rearing purposes; the duration of 8.57 days at $25^{\circ} \mathrm{C}$ is longer than those reported for other members of Pentatomidae such as Podisus nigrispinus (Dallas) (4.00 days) (Vacari et al., 2007), Podisus distinctus (Dallas) (5.20 days) (Santos et al., 2004) and Brontocoris tabidus (Signoret) (3.50 days) (Fernandes et al., 1996) and 5.60 days (Jusselino-Filho et al., 2003). However, S. decastigmus showed higher survival for the embryonic period than these other predators. Probably longer periods of embryonic development is a characteristic of this species, because when the temperature was high, although this period decreased, it was still longer than those reported for other members of Pentatomidae at lower temperatures (Fernandes et al., 1996; Jusselino-Filho et al., 2003; Santos et al., 2004; Vacari et al., 2007).

As noted by Coursey and Esselbaugh (1962), pentatomids typically have five instars. The number of instars of $S$. decastigmus was not affected by the temperature, since the nymphs passed through five instars at all temperatures tested. However, the temperature was a determining factor in the duration of all nymphal instars. For nymphs exposed to temperatures of $20^{\circ} \mathrm{C}$ the duration of each instar was longer, and shorter durations predominated in nymphs exposed to $30^{\circ} \mathrm{C}$.

The survival of $S$. decastigmus nymphs at $25^{\circ} \mathrm{C}$ was higher than that of $P$. nigrispinus reared on Tenebrio molitor L. (Coleoptera: Tenebrionidae) (68\%) and Spodoptera frugiperda (J.E. Smith) (Lepidoptera: Noctuidae) (64\%) (Oliveira et al., 2004), and of P. distinctus reared on Musca domestica (L.) (Diptera: Muscidae) larvae (60\%) (Lacerda et al., 2004), and T. molitor (76\%) (Santos et al., 2004). This difference may be related to food quality, since $S$. decastigmus was fed on prey that, despite being laboratory-reared, is natural; while the studies of these other predators used prey reared on artificial diets.

The nymphal period of 20 days at $25{ }^{\circ} \mathrm{C}$ found for $S$. decastigmus fed with $M$. ochroloma larvae indicates that this prey species may be appropriate for rearing this predator, because they provide suitable nutritional resources for its development, as reported for another pentatomid predator (Oliveira et al., 2004). Since at these temperatures the prey consumption was lowest, this translates to a reduction in production costs. The larger number of prey consumed at $20^{\circ} \mathrm{C}$ is related to the longer developmental period at this temperature, since nymphs that take longer to develop require more food. However, this relationship did not obtain at the higher temperature $\left(30^{\circ} \mathrm{C}\right)$, where the development time was reduced; however, the number of prey consumed was higher than that consumed by nymphs kept at $25^{\circ} \mathrm{C}$. Possibly this is related to the accelerated metabolism at higher temperatures, causing the insects to require more energy to reach the next stage.

The total life-cycle duration of $S$. decastigmus is similar to that of $S$. cincticeps at $25^{\circ} \mathrm{C}$ fed on $M$. domestica (30.2 days) and T. molitor (30.5 days) (Zanuncio et al., 1992).

The number of $M$. ochroloma larvae predated by $S$. decastigmus was higher than that of $P$. nigrispinus in the laboratory at $28 \pm 1{ }^{\circ} \mathrm{C}, 53 \pm 5 \% \mathrm{RH}$ and a photophase of $14 \mathrm{~h}$, which was 43.10 larvae of Tuta absoluta (Meyrick) 
(Lepidoptera: Gelechiidae) (Vivan et al., 2002) and 15.2 larvae of Plutella xylostella (L.) (Lepidoptera: Pyralidae) at $25 \pm 1{ }^{\circ} \mathrm{C}, 70 \pm 10 \% \mathrm{RH}$, and a photophase of $12 \mathrm{~h}$ (Xavier et al., 2009). This larger amount of prey consumed is likely related to their size and to the amount of nutrients contained, since the larvae of M. ochroloma are smaller than the prey used by these investigators.

In summation, for the purpose of laboratory rearing with a view toward optimizing the production of predators, the temperature of $25{ }^{\circ} \mathrm{C}$ was optimum for nymphal development of $S$. decastigmus, as shown by their higher survival rate and lower consumption of M. ochroloma larvae. With respect to the use of $S$. decastigmus for the purpose of biological control under field conditions, lower rearing temperatures lead to a higher consumption of larvae and a longer nymphal developmental period.

\section{Acknowledgements}

Ayres Menezes de Oliveira Jr. of the "Universidade Estadual de Londrina" for identifying Microtheca, and Aline Barcellos Prates dos Santos from the "Museu de Ciências Naturais da Fundação Zoobotânica do Rio Grande do Sul" for the identification of $S$. decastimus. The Conselho Nacional de Desenvolvimento Científico e Tecnológico (CNPq) provided a scholarship.

\section{References}

AMEEN, A.O. and STORY, R.N., 1997. Fecundity and longevity of the yellowmargined leaf beetle (Coleoptera: Chrysomelidae) on crucifers. Journal of Agricultural Entomology, vol. 14, no. 1, pp. 157-162.

COURSEY, R.M. and ESSELBAUGH, C.O., 1962. Descriptions of the nymphal stages of some North American Pentatomidae (Hemiptera: Heteroptera). Annals of the Entomological Society of America, vol. 55, no. 3, pp. 323-342. http://dx.doi.org/10.1093/ aesa/55.3.323.

DEQUECH, S.T.B., SAUSEN, C.D., LIMA, C.G. and EGEWARTH, R., 2008. Efeito de extratos de plantas com atividade inseticida no controle de Microtheca ochroloma Stal (Col.: Chrysomelidae), em laboratório. Revista Biotemas, vol. 21, no. 1, pp. 41-46.

FASULO, T.R., 2005 [viewed 23 March 2012]. Yellowmargined leaf beetle, Microtheca ochroloma Stål [online]. Florida: Institute of Food and Agricultural Sciences, University of Florida. EENY-348. Available from: http://edis.ifas.ufl.edu/pdffiles/IN/IN62500.pdf

FERNANDES, L.G., CARVALHO, C.F., BUENO, V.H.P. and DINIZ, L.C., 1996. Aspectos biológicos de Brontocoris tabidus Signoret, 1852 e Podisus nigrispinus Dallas (Hemiptera: Pentatomidae). Revista Cerne, vol. 2, no. 1, pp. 1-10.

JUSSELINO-FILHO, P., ZANUNCIO, J.C., FRAGOSO, D.B., SERRÃO, J.E. and LACERDA, M.C., 2003. Biology of Brontocoris tabidus (Heteroptera: Pentatomidae) fed with Musca domestica (Diptera: Muscidae) larvae. Brazilian Journal of Biology $=$ Revista Brasileira de Biologia, vol. 63, no. 3, pp. 463-468. http://dx.doi. org/10.1590/S1519-69842003000300012. PMid:14758705.

LACERDA, M.C., FERREIRA, A.M.R.M., ZANUNCIO, T.V., ZANUNCIO, J.C., BERNARDINO, A.S. and ESPINDULA,
M.C., 2004. Development and reproduction of Podisus distinctus (Heteroptera: Pentatomidae) fed on larva of Bombyx mori (Lepidoptera: Bombycidae). Brazilian Journal of Biology $=$ Revista Brasileira de Biologia, vol. 64, no. 2, pp. 237-242. http:// dx.doi.org/10.1590/S1519-69842004000200008. PMid:15462296.

OLIVEIRA, H.N.D., PRATISSOLI, D., PEDRUZZI, E.P. and ESPINDULA, M.C., 2004. Desenvolvimento do predador Podisus nigrispinus alimentado com Spodoptera frugiperda e Tenebrio molitor. Pesquisa Agropecuária Brasileira, vol. 39, no. 10, pp. 947-951. http://dx.doi.org/10.1590/S0100-204X2004001000001.

PARRA, J.R.P., BOTELHO, P.S., CORREAA-FERREIRA, B.S, and BENTO, J.M.S., 2002. Controle biológico: uma visão inter e multidisciplinar. In: J.R.P. PARRA, P.S. BOTELHO, B.S. CORRÊA-FERREIRA and J.M.S. BENTO, eds. Controle biológico no Brasil: parasitoides e predadores. São Paulo: Manole, pp. 125-142.

PINTO, C.M.F., PEREIRA, J.M. and PAULA JUNIOR, T.J., 2001. Agricultura alternativa no contexto mundial. Informe Agropecuário, vol. 22, no. 212, pp. 80-83.

PONCIO, S., DEQUECH, S.T.B., STURZA, V.S., LISSNER, R.A.D., PERLIN, L.F., ROSALINO, P.K. and RIBEIRO, L.P., 2010. Primeiro relato de Stiretrus decastigmus no Brasil predando Microtheca ochroloma. Ciência Rural, vol. 40, no. 5, pp. 12031205. http://dx.doi.org/10.1590/S0103-84782010005000069.

SANTOS, G.P., ZANUNCIO, T.V., RIBEIRO, G.T., DA SILVA, E.P. and ZANUNCIO, J.C., 2004. Influência da temperatura no desenvolvimento ninfal de Podisus distinctus (Dallas) (Heteroptera: Pentatomidae). Revista Cerne, vol. 10, no. 2, pp. 213-221.

SILVA, E.N., SANTOS, T.M. and RAMALHO, F.S., 1996. Desenvolvimento ninfal de Supputius cincticeps Stal (Hemiptera: Pentatomidae) alimentado com curuquerê-do-algodoeiro. Anais da Sociedade Entomológica do Brasil, vol. 25, no. 2, pp. 103-108.

SILVA, F.A.S., 1996. FASE: the ASSISTAT Software: statistical assistance. In: Proceedings of the 6th International Conference on Computers in Agriculture, 1996, Cancun, Mexico. Cancun: American Society of Agricultural Engineers, pp. 246-298.

STURZA, V.S., PONCIO, S., DORFEY, C., DEQUECH, S.T.B., BOLZAN, A. and WALKER, M., 2012. Ocurrence of Stiretrus decastigmus Herrich-Schaeffer (Hemiptera: Pentatomidae) preying Microtheca semilaevis Stal (Coleoptera: Chrysomelidae). Neotropical Entomology, vol. 41, no. 1, pp. 81-82. http://dx.doi. org/10.1007/s13744-011-0013-9. PMid:23950015.

VACARI, A.M., OTUKA, A.K. and DE-BORTOLI, A.S., 2007. Desenvolvimento de Podisus nigrispinus (Dallas, 1851) (Hemiptera: Pentatomidae) alimentado com lagartas de Diatraea saccharalis (Fabricius, 1794) (Lepidoptera: Crambidae). Arquivos do Instituto Biológico, vol. 74, no. 3, pp. 259-265.

VIVAN, L.M., TORRES, J.B., VEIGA, A.F.S.L. and ZANUNCIO, J.C., 2002. Comportamento de predação e conversão alimentar de Podisus nigrispinus sobre a traça-do-tomateiro. Pesquisa Agropecuária Brasileira, vol. 37, no. 5, pp. 581-587. http://dx.doi. org/10.1590/S0100-204X2002000500002.

WANDERLEY, M.J.A. and RAMALHO, F.S., 1999. Efeitos da temperatura no desenvolvimento de Supputius cincticeps (Stäl) (Heteroptera: Pentatomidae) alimentado com larvas de Musca domestica L. Anais da Sociedade Entomológica do Brasil, vol. 28, no. 1, pp. 121-129. http://dx.doi.org/10.1590/S030180591999000100013 .

XAVIER, M.R., DE-BORTOLI, A.S., VACARI, A.M., LAURENTIS, V.L. and MAGALHÃES, G.O., 2009. Aspectos biológicos e tabela 
de vida de Podisus nigrispinus (DALLAS, 1851) alimentado com lagartas de Plutella xylostella (L., 1758) em folha de couve (Brassica oleracea L.). In: Anais do XXI Congresso de Iniciação Cientifica da Unesp, 2009, Jaboticabal, São Paulo. Jaboticabal: UNESP, pp. 557-560.

ZANUNCIO, J.C., NASCIMENTO, E.C., SANTOS, G.P. and ARAÚJO, F.S., 1991. Aspectos biológicos do predador Podisus connexivus (Bergroth, 1891) (Hemiptera: Pentatomidae). Anais da Sociedade Entomológica do Brasil, vol. 20, no. 2, pp. 243-249.

ZANUNCIO, T.V., ZANUNCIO, J.C., VILELA, E.F. and SARTÓRIO, R.C., 1992. Aspectos biológicos da fase adulta de Supputius cinsticeps Stal, 1860 (Hemiptera: Pentatomidae), predador de lagartas desfolhadoras de eucalipto. Instituto de Pesquisas e Estudos Florestais, vol. 45, no. 1, pp. 35-39. 